\title{
The Idea of Constitutional Identity in the Modern Constitutional Thought
}

\section{国 Anahit Manasyan}

Associate Professor, Chair of Constitutional Law, Yerevan State University, Candidate of Juridical Sciences. Address: 9 Pirumyanner Str., Yerevan 0054, Armenia. E-mail: a_manassian@yahoo.com

\section{昰目 Abstract}

The constitutional identity is the originality, individuality and uniqueness of the given constitutional system, which includes not just the originally existing features, providing the given system with a quality of uniqueness, but also the features of larger systems, which are borrowed by the constitutional system and with which the latter starts to identify itself. Because of it, the constitutional identity should be perceived not as a feature, initially belonging to a given social system, but a feature, which is formed and transformed as the result of social interactions. At the same time, all the newly formed peculiarities, including the ones are borrowed from other systems, also become features, defining originality and individuality of the given system. Hence, while borrowing constitutional-legal peculiarities of international and supranational institutions or of any other state, it should be taken into account that mechanical import or not accepting and artificially preserving the mechanically imported features will not in any way contribute to finding a balance between peculiarities of a concrete constitutional system and features borrowed from the mentioned systems. This, in its turn, will lead to the complete distortion of the idea of constitutional identity. At the contemporary stage of development of constitutional law doctrine it is preferable to discuss the notions of "state identity" and "constitutional identity" not as a correlation of correspondingly the whole and the part, but from the viewpoint of different levels, though in some cases they can have points of coincidence. The reason is that within the framework of the mentioned doctrine notions "Constitution", "Constitutional stability" should per se be perceived not just from the aspect of the written text of the Constitution, but from the viewpoint of constitutional values and their implementation in real social development.

\section{O-1国 Keywords}

constitutional identity; constitutional systems; national identity; state identity; international commitments; Constitution.

Citation: Manasyan A. (2018) The Idea of Constitutional Identity in the Modern Constitutional Thought. Pravo. Zhurnal Vysshey shkoly ekonomiki, no 3, pp. 81-98 (in English)

DOI: $10.17323 / 2072-8166.2018 .3 .81 .98$ 


\section{Introduction}

One of the most significant ideas from the viewpoint of constitutional stability and stable democracy is constitutional identity. There are different definitions of it employed in the literature, but each of them perceives constitutional identity just from this or that particular criterion. As the result, both in Armenian and foreign legal thought there is no unanimous approach towards the discussed notion and its content.

Laurence Tribe, for instance, defines "constitutional identity" as follows: "The very identity of 'the Constitution' - the body of textual and historical materials from which fundamental constitutional norms are to be extracted and by which their application is to be guided ..."1. To Gary Jacobsohn's mind, a constitution acquires an identity through experience, its identity neither exists as a discrete object of invention nor as a heavily encrusted essence embedded in a society's culture, requiring only to be discovered. Identity emerges dialogically and represents a mix of political aspirations and commitments that are expressive of a nation's past, as well as the determination of those within the society who seek, in some ways, to transcend that past $^{2}$.

Michel Rosenfeld, while studying peculiarities of constitutional reforms and the process of development of the Constitution, also analyzes the notion "identity". He considers the latter as originality, uniqueness of internal and external factors, conditioning the necessity of constitutional amendments, as well as socio-economical, social-political, spiritual-cultural peculiarities of each state ${ }^{3}$. Mr. Rosenfeld distinguishes five main constitutional models - French, German, American, Spanish and the model of the European Union ${ }^{4}$. Herewith, the necessity of differentiating national and supranational identities is emphasized (for instance, identity of EU and identity of EU member-states).

The presented definitions lead us to a conclusion that there is no unanimous approach to the term "constitutional identity" and its content. Moreover, it is obvious that in the context of analyzing the discussed issue notions "constitutional identity" and "national identity" are considered as identical ${ }^{5}$. At the same time, as the

${ }^{1}$ See Tribe L. A Constitution We Are Amending: In Defense of a Restrained Judicial Role // Harvard Law Review, 1983, vol. 97, pp. 433-440.

2 See: Jacobsohn G. Constitutional Identity // The Review of Politics of University of Notre Dame. 2006, vol. 3, pp. 361-397.

${ }^{3}$ See: Rosenfeld M. The Problem of "Identity" in Constitution-Making and Constitutional Reform // Working Paper. 2005, no 143, p. 24.

${ }^{4}$ See: Rosenfeld M. Constitution-making, Identity Building, and Peaceful Transition to Democracy: Theoretical Reflections Inspired by the Spanish Example // Cardozo Law Review. 1998, vol. 19, p. 1891.

${ }^{5}$ See: Ispolinov A. (2017) Prioritet prava Evropeyskogo Soyuza i natsional'naya (konstitutsionnaya) identichnost' v resheniyakh Suda ES i konstitutsionnykh sudov gosudarstv — chlenov EC [The Priority of 
presented definitions regarding constitutional identity indicate, the approach to the issue whether identity is a phenomenon, initially belonging to a constitutional system, or it is formed over time, parallel to the development of social characteristic for the given system, is not unanimous, too.

Hence, in this context we consider necessary to analyze the following issues: Are the notions "national identity" and "constitutional identity" actually identical? What content does the idea "constitutional identity" have? Is identity a phenomenon, originally belonging to a constitutional system, forming its essence and being its basis or is it being formed over time, parallel to the development of social relations? What kind of role can identity play for guaranteeing constitutional stability and ensuring normal course of constitutional development?

\section{Constitutional Identity: Definition and Axiological Description}

According to encyclopedic formulation the term "identity" is defined as "being itself", "being unique", "complex of typical peculiarities", "existence", "essence", "originality", "individuality".

Hence, we believe that all manifestations of identity firstly presuppose "uniqueness", "originality", "individuality" of the concrete phenomenon. Analogically, in its general sense constitutional identity is the originality, individuality of the concrete constitutional system, everything that differentiates the given system from the others.

It is emphasized in literature that identity is not a feature, originally belonging to a person, but a relationship, which is formed, formulated and transformed just during social interactions. Herewith, in its literal sense identity can be typical just for individuals, as just individuals can be characterized by subjectivity and, correspondingly, just individuals can ascribe themselves with concrete features and definitions. Hence, identity can be attributed to groups just in allegorical, metaphorical sense ${ }^{6}$.

Identity can be differentiated into two layers - individual (internal) and social (external). In comparison with individual identity, which is the complex of typical peculiarities, providing an individual a quality of uniqueness, social identity is the result of an individual's self-identification with expectations and norms of his/ her social environment. At the same time, it is emphasized in literature that the mentioned two layers cannot be differentiated in absolute sense, as an individual's comprehension about himself/herself, which is perceived as his/her own and indivisible from his/her identity, is also a result of interiorization of social norms. At

EU Law and National (Constitutional) Identity in the Decisions of EU Court and Constitutional Courts of EU Member States]. Available at: https://zakon.ru/publication/prioritet_prava_evropejskogo_soyuza_i_ nacionalnaya_konstitucionnaya_identichnost_v_resheniyah_suda_e (accessed: 18.04.2018)

${ }^{6}$ See: Novaya filosofskaya entsiklopedia [New Philosophical Encyclopedia]. Available at: https://dic. academic.ru/dic.nsf/enc_philosophy/419 (accessed: 18.04.2018) 
the same time, individual's own norms and comprehension not always coincide with norms and roles accepted by him/her during social interrelations. Hence, individual "myself" is formed in the result of finding a certain balance between individual and social identity. Social identity, in its turn, is classified into various types - professional, ethnic, regional, political, national etc..

The above-mentioned leads us to a conclusion that constitutional identity per se is a feature typical to an individual and can be used as a group peculiarity just in conditional sense. Hence, taking into account the fact that in this context we analyze constitutional identity as a category typical for a concrete social community, it is obvious that we use the discussed term in conditional sense.

Taking into account the provided analysis, we argue that constitutional identity characterizes originality, individuality and uniqueness of concrete constitutional system. The individual dimension of the latter is the complex of typical peculiarities, providing the concrete constitutional system with a quality of uniqueness, whereas, the social dimension is the result of self-identification of a constitutional system with peculiarities of comprising it larger systems. Moreover, it is important to take into account that, as mentioned above, the features of a constitutional system can in some cases not coincide with the peculiarities borrowed during interrelations with comprising it larger systems. At the same time, identity is formed in the result of finding certain balance between the mentioned two dimensions.

Hence, constitutional identity is the originality, individuality and uniqueness of the concrete constitutional system, which includes not just the originally existing features, which provide the given system with a quality of uniqueness, but also the features of the larger systems, which are borrowed by the constitutional system and with which the latter starts to identify itself.

The above-mentioned leads us to a conclusion that constitutional identity should be perceived as not a feature, initially belonging to the given social system, but a feature, which is formed and transformed as the result of social interactions. At the same time, it should be noted that all the newly formed peculiarities, including the ones which are borrowed from other systems, also become features, defining originality and individuality of the given system.

Hence, in this case the general conclusion is that there are constant interrelations between equivalent systems, as well as between the latter and larger systems, comprising them. Moreover, as the identity of the concrete system is formed in the result of finding a certain balance between individual and social identities, we believe that during this process the following important circumstances should be taken into consideration: 1 . Such peculiarities should be borrowed, which can be acceptable for the concrete system, 2. Those borrowed peculiarities, with which the concrete system cannot identify itself, should be rejected. At the same time, it should be emphasized that though various systems have interrelations also with equivalent systems, this has an impact on forming identity just so far as the pecu- 
liarities borrowed from these systems become features, characterizing the uniqueness of a concrete system. Whereas, concrete systems can self-identify themselves not with equivalent systems, but with larger systems, comprising them.

We do believe that from the viewpoint of constitutional identity the above firstly concerns interrelations between various constitutional systems and international or supranational institutions, comprising them. From this aspect one should take into account that constitutional identity of a concrete constitutional system is formed in the result of finding a balance between the typical features, providing the system a quality of uniqueness, and peculiarities borrowed from other systems. Hence, while borrowing constitutional-legal peculiarities of international and supranational institutions or of any other state, one should take into consideration the above-mentioned circumstance and the fact that mechanical import or not accepting and artificial preserving the mechanically imported features will not in any way contribute to finding a balance between peculiarities of a concrete constitutional system and features borrowed from the mentioned institutions. This, in its turn will lead to the entire distortion of the idea of constitutional identity.

Discussing the issue on the example of the Republic of Armenia (henceforth - RA), we would like to mention that constitutional regulations regarding, for instance, the Armenian Apostolic Holy Church, the state symbols, the capital of the Republic of Armenia are typical peculiarities, initially providing a quality of uniqueness to the RA constitutional system. Whereas, for instance, the basic principles, underlying the limitation of fundamental rights and freedoms - proportionality, certainty, inviolability of the essence of the provisions on basic rights and freedoms - are borrowed from other constitutional systems and from international-legal practice. At the same time, it should be noted that merely the fact of their adoption per se indicates that a concrete constitutional system has found a balance between its individual and social identities, hence, has also started to identify itself with the mentioned borrowed peculiarities. In this context it should be stated that many of the values of the RA constitutional system, which are borrowed from other legal systems, for instance, constitutional regulations regarding human dignity, separation and balance of powers, right to life, guaranteeing local self-governance, etc., are already perceived as an inherent part of the RA constitutional system and as features, providing the latter a quality of uniqueness. The above-mentioned itself presupposes that the noted borrowed peculiarities have become features, characterizing individuality and uniqueness of the concrete system, in this case - the RA constitutional system, and in normal situation the latter can't perceive them differently. Otherwise, when the impossibility of self-identification of a concrete system with its borrowed peculiarities becomes obvious, the latter should reject the idea of their artificial preservation.

We believe that the above-mentioned circumstances and conclusions are the main guarantees for ensuring constitutional stability and stable democracy, as well as normal course of constitutional developments. 


\section{Respect for National-State Identities by International Organizations}

In this context we consider necessary to analyze the issues related to the respect of national-state identities of member-states by various international and supranational systems, which has an exceptional importance not just from the aspect of normal international legal relations, but also from the aspect of modern constitutional doctrine.

The main questions, arising with regard to the presented issue, are the following: Is the constitutional identity of a concrete constitutional system an absolute phenomenon? Is it practically realistic to speak about its respect by the mentioned organizations? What kind of mechanisms do we need for the normal regulation of the discussed issue and for the protection of concrete constitutional system identity?

In order to examine the above-mentioned issues we firstly consider necessary to analyze a number of particular examples, existing in international practice.

The Constitutional Court of the Russian Federation, for instance, in its Decision 12-П/2016 of 12 April 2016 emphasized that the effectiveness of norms of the European Convention for the Protection of Human Rights and Fundamental Freedoms is conditioned with respect for national constitutional identities (our underlining - A.M.) by the European Court ${ }^{7}$.

Within the framework of the European Union law interrelations of the notions "national identity" and "constitutional identity" are also discussed with the purpose of presenting the issues related to the obligation of the Union to respect national identities of the Member-States. Article 6 (3) of Maastricht Treaty stipulates that ... the Union shall respect the national identities of its Member-States (our underlining - A.M.). The Lisbon Treaty reformulated the provision on respect for national identities of the Member-States as follows: The Union shall respect the equality of Member States before the Treaties as well as their national identities, inherent in their fundamental structures, political and constitutional, inclusive of regional and local self-government ${ }^{8}$. At the same time, it is important to note that almost all the Constitutional Courts of the EU Member-States admit the supremacy and primacy of the EU law over their national legislation. Whereas, the majority of these courts doesn't recognize the supremacy of the EU law over their constitutions?.

It is normal that the approaches regarding the issue are diverse in various constitutional systems. Not having an aim to reveal the details of each of these ap-

7 The Constitutional Court of the Russian Federation. Decision 12-П/2016 of 12 April 2016. Available at: http://doc.ksrf.ru/decision/KSRF Decision 230222.pdf. (accessed: 18.04.2018)

${ }^{8}$ See: National Identity, Nationalism and Constitutional Change. 2009 Available at: http://www.law. ed.ac.uk/_data/assets/pdf_file/0011/35939/chap1_intro.pdf (accessed: 18.04.2018); Besselink L. National and Constitutional Identity before and after Lisbon // Utrecht Law Review, 2010, no 3, p. 43.

${ }^{9}$ See: Besselink L. Op. cit. P. 44-49. 
proaches, we consider necessary for the purposes of this study to emphasize the following: to our mind, the basis for the analysis of these viewpoints should be the circumstance how and how much the concrete state restricts its sovereignty in favor of an international or supranational organization.

Touching upon the example of the Republic of Armenia on the discussed issue, it should be noted that, according to the RA Constitution, the Constitution shall have supreme legal force (the Constitution of the Republic of Armenia. Article 5). In case of conflict between the norms of international treaties ratified by the Republic of Armenia and those of laws, the norms of international treaties shall apply. International treaties contradicting the Constitution may not be ratified (the Constitution of the Republic of Armenia. Article 116).

The above-mentioned leads us to a conclusion that the Constitution has a peculiar status both from the viewpoint of the hierarchy of legal norms and also from the aspect of its key role in the constitutional system of the Republic of Armenia.

Taking this into account, the Constitution defined that the Constitutional Court, as prescribed by the Law on the Constitutional Court, prior to the ratification of an international treaty, shall determine the compliance of the commitments enshrined therein with the Constitution (the Constitution of the Republic of Armenia. Article 168).

This indicates that consideration of cases on conformity of commitments enshrined in the international treaty subjected to ratification with the Constitution is an example of a preliminary mandatory constitutional supervision and is aimed to prevent ratification by the Republic of Armenia of international treaties, defining contradicting the Constitution commitments. This circumstance, in its turn, excludes ratification of international treaties and correspondingly, taking over commitments, which distort the essence of our constitutional identity.

In this context we would like to emphasize that unlike the majority of constitutional courts, existing across the world, which don't have a rich practice of considering such cases, the RA Constitutional Court has examined a rather big number of cases related to the discussed issue. The reason, as we already mentioned, is the preliminary and obligatory nature of the noted proceedings.

Moreover, though in the result of consideration of the majority of these cases the Constitutional Court decided about conformity of the obligations enshrined therein with the RA Constitution, there are also cases in the practice of the mentioned body, when in the result of examination of these cases a negative decision was made or the Constitutional Court, declaring the commitments enshrined in the international treaty in conformity with the Constitution, expressed fundamental legal positions on their perception by the Republic of Armenia, hence also, on their such interpretation, which would be in conformity with the RA Constitution. Herewith, these legal positions became crucial for the whole further process of the respective treaties' ratification and predetermined the whole course of the latter. 
In this context we would like to mention correspondingly the following examples from the RA Constitutional Court practice: Decision DCC-502 of 13 August 2004 on the case concerning the determination of the issue regarding the conformity of the obligations stipulated by the Rome Statute of the International Criminal Court (with attached Declaration) signed on 17 July 1998 in Rome with the Constitution of the Republic of Armenia and Decision DCC-850 of 12 January 2010 on the case on determining the issue of conformity with the Constitution of the Republic of Armenia of the obligations stipulated by the Protocol on the Establishment of Diplomatic Relations between the Republic of Armenia and the Republic of Turkey and by the Protocol on Development of Relations between the Republic of Armenia and the Republic of Turkey signed in Zurich on 10 October 2009.

The presented examples indicate that in all the cases when the essence of our constitutional identity was endangered, the state itself denied to take over corresponding commitments, hence also, to borrow respective peculiarities from other systems and to perceive them as features, characterizing its uniqueness.

Moreover, the regulation prescribed in the RA Constitution in the result of constitutional amendments of 6 December 2015, according to which the issues related to the accession by the Republic of Armenia to supranational international organizations, as well as those related with territorial changes of the Republic of Armenia shall be resolved through referenda, is worth mentioning. The decision on holding a referendum in these cases shall, upon recommendation of the Government, be adopted by the National Assembly, by majority of votes of the total number of Deputies (the Constitution of the Republic of Armenia. Article 205).

In this context we would also like to mention that international law is itself based on the idea of "state consent" and international law cannot bind a state without its consent. Though such a conclusion can in some sense be seemed extreme, it shows the fundamental role the institute of consent plays in international legal system. In other words, the basis of the modern international law is the principle of "state consent" 10 . Though in case of supranational organizations the noted principle should be discussed with some reservations, but, to our mind, the latter thoroughly applies also to the mentioned relations when we speak about the scope, format and ways of restricting the sovereignty.

The above-mentioned will show that in all cases states themselves decide the scope of restriction of their sovereignty, which can be acceptable for them from the viewpoint of their constitutional identities in interrelations with international and supranational organizations. Herewith, the mentioned concerns not just the process of taking over corresponding commitments and the possible solutions, existing for this in a concrete constitutional system, but also possible solutions for

${ }^{10}$ See: Guzman A. The Consent Problem in International Law. Berkeley Program in Law and Economics // Working Paper Series, pp. 4-5. Available at: https://escholarship.org/content/qt04x8x174/ qt04x8x174.pdf (accessed: 18.04.2018) 
rejecting the borrowed peculiarities in all cases, when the concrete constitutional system cannot identify itself with them.

The above-mentioned indicates that in fact it is realistic to speak about the respect by various international or supranational organizations towards the identity of the concrete constitutional system, but in this context we should take into account an important point - the fact that the limits, the scope of respect towards the national constitutional identity are already predetermined, herewith, they are predetermined with the scope, by which a concrete constitutional system has agreed to restrict its sovereignty.

\section{Correlation of the Ideas "National Identity" and "Constitutional Identity"}

The next issue, we consider necessary to analyze in this context, is whether the terms "national identity" and "constitutional identity" are identical.

It is obvious that nation and Constitution, nation and constitutional system cannot be identical. Hence, the main point, which should be analyzed in this context, is the following: Can the notion "constitutional identity" not have an own content and be totally identical with the content of the notion "national identity"?

At first we consider necessary to analyze the approach presented in literature, according to which we are used to use the terms "state" and "nation" as synonyms, forgetting that they concern different dimensions - accordingly political and cultural ${ }^{11}$. Hence, in this case a question arises whether in the given context the point concerns state or national identity.

We would like to emphasize that the terms "state" and "nation" are not synonyms and can't be identical in the sense of their content. Different nations can be united within the frames of one state and analogically, so called, "nations without states" can exist. Hence, it is obvious that the notions "state identity" and "national identity" can't be absolutely identical.

It should be noted that the term "state identity" is mainly used in Russian-language literature ${ }^{12}$. Moreover, in Russian-language publications of recent years the idea of "state-national identity" also exists ${ }^{13}$. Whereas, in English-language litera-

${ }^{11}$ See: National Identity, Nationalism and Constitutional Change...Available at: http://www.law.ed.ac. uk/_data/assets/pdf_file/0011/35939/chap1_intro.pdf (accessed: 18.04.2018); Besselink L. Op. cit. P. 42.

12 See, for instance: Sanina A., Pavlov A. (2015) Gosudarstvennaya identichnost': soderzhanie ponyatiya i postanovka problemy [State Identity: Concept and Issue]. Upravlencheskoe konsul'tirovanie, no 9 , pp. 30-40; Rubtsova M., Sanina A. (2012) Gosudarstvennaya identichnost' kak factor upravlyaemosti sovremennym obshchestvom [State Identity as a Factor of Running Modern Society]. Zhurnal sotsiologii $i$ sotsial'noy antropologii, no 3, pp. 86-97.

${ }^{13}$ See, for instance: Bushuev V., Titov V. (2014) Natsional'no-gosudarstvennaya identichnost' $v$ sovremennom mire $i$ rol' istoricheskoy politiki $v$ ee formirovanii (teoretiko-metodologicheskiy analiz) 
ture the term "state identity" is practically not used, and the questions regarding the mentioned issue are analyzed within the frames of the idea "national identity". Moreover, in the result of the study of their content it becomes obvious that in the discussed context the point is not about national identity in its classical sense, but about national identity in case of, so called, "coincidence" of the phenomena nation and state. At the same time, we think that the reason of the mentioned not definite use of the discussed terms is also linguistic, as in English the word "state" is presented as a synonym for the word "nation" 14 . Meanwhile, taking into account the existing positions and analysis on interconnections of national and constitutional identities, we believe that in this context the terms "state identity" and "national identity" are used as synonyms. Moreover, this is also often emphasized in various scientific works ${ }^{15}$.

In the above-mentioned context the notion "national identity" is characterized as the existence of the below-mentioned three main ideas in conscience of majority of the population of the state: 1 . A general past perceived positively by the social conscience and/or a general experience of statehood, 2. A complex of values common for the given social community, 3. General responsibility for the future of the state. Identity, in its turn, is characterized as self-identification of individuals or a group of people with a larger and more essential group. Moreover, "identity impacts on the self-conscience of a person, vesting him/her with a perception that the group, with which he/she identifies himself/herself, is endowed with peculiar features, differentiating it from other groups"16.

Hence, it is obvious that the terms "state identity" and "national identity" can coincide just in some situations - in cases of, so called, "coincidence" of phenomena nation and state. At the same time, they can't be considered absolutely identical for all situations.

Taking the above-mentioned into account, we do not aim to deepen into discussion of an issue, which is not an object for the given study, analyzing the latter just from the viewpoint of correlation of constitutional identity with the mentioned notions. From this viewpoint it is obvious that if we speak about national identity in its classical sense, the latter is a too wide notion and can't be identical with the idea of "constitutional identity". Taking this circumstance into account, in this context we use the term "state identity" as a conditional notion, wide category

[National State Identity in the Modern World and the Role of Historical Politics in its Formation]. Available at: https://cyberleninka.ru/article/v/natsionalno-gosudarstvennaya-identichnost-v-sovremennom-mirei-rol-istoricheskoy-politiki-v-ee-formirovanii-teoretiko (accessed: 18.04.2018)

${ }^{14}$ See: English Oxford Living Dictionaties. Available at: https://en.oxforddictionaries.com/thesaurus/ state (accessed: 18.04.2018)

${ }^{15}$ See: Kuznetsov K.A., Shchelin P.A. (2014) Natsional'naya identichnost' i ustoychivaya gosudarstvennost' [National Identity and Stable Statehood]. Sravnitel'naya politika, no 1, pp. 31-36.

${ }^{16}$ Ibid. P. 31-32. 
with the aim of characterizing the idea of self-identification of the population of the state with each other and the issues regarding this.

What about the interrelations of ideas "state identity" and "constitutional identity" in the above-noted sense, we would like to mention that, to our mind, at the modern stage of the development of constitutional law doctrine it is just preferable to discuss these notions from the viewpoint of different layers. The reason is that within the frames of the mentioned doctrine notions "Constitution", "constitutional stability" should per se be perceived not just from the aspect of the written text of the Constitution, but from a wider viewpoint - from the one of constitutional values and their realization in real life. Hence, even if previously - in case of considering the constitutional system in the context of written text of the Constitution, one could consider the notions "state" and "constitutional system" as correlation of correspondingly the whole and the part, and in the result draw the same conclusion for the ideas "state identity" and "constitutional identity", nowadays such an ambiguous conclusion can be problematic. In particular, it is obvious that the fundamental provisions on the main characteristics of the state - permanent population, defined territory, existence of state power, possibility to form relations with other states ${ }^{17}$, sovereignty, universal nature of the state $\operatorname{acts}^{18}$, etc., are reflected in the constitutional text. Hence, if the above-mentioned conclusion on the whole and the part can be reasonable if we discuss the issue just from the aspect of the constitutional text, the same conclusion cannot apply to the cases when we consider the Constitution and constitutional system from the viewpoint of constitutional values and their realization in real life.

Hence, we argue that state identity and constitutional identity can't be considered from the viewpoint of correlation of correspondingly the whole and the part. Moreover, though they can have concrete points of coincidence, we believe that they are notions, which belong to different layers, hence, they should also be touched upon from the aspect of different layers.

\section{Constitutional Identity and Constitutional Developments}

Constitutional identity plays an important role for the proper implementation of constitutional developments. The presented analysis shows that constitutional identity is a phenomenon, constituting the quality and axis of a constitutional system. This, in its turn, presupposes that issues regarding it should always be taken into consideration during the whole process of the development of the Constitu-

17 See: Crawford J. The Criteria for Statehood in International Law. Available at: https://www.ilsa. org/jessup/jessup13/British\%20Yearbook\%20of\%20International\%20Law-1977-Crawford-93-182.pdf (accessed: 18.04.2018)

18 See: Morozova L. Teoriya gosudarstva i prava [Theory of Law and State]. Moscow: Yurist, 2010, pp. $46-47$. 
tion. Hence, in this context we would like to analyze also the interrelations between constitutional identity and constitutional developments.

At first, it should be noted that "stability", "changeability" and "development" of the Constitution are not mutually exclusive terms. The essence of stability isn't based on the idea of preserving the system from changes, but on the idea of establishing opportunities for taking the mentioned changes into account. At the same time, the above-mentioned shouldn't presuppose a possibility to thoroughly change the "core", "kernel", the essence of the system. Moreover, in order to be considered as a development, amendments should have a qualitative nature, that is, there should be a transition from one qualitative condition of a system to another ${ }^{19}$, and a qualitatively new condition of a system, in this case a Constitution, should be formed. At the same time, as it was mentioned above, we should take into account that the notion "development of the Constitution" presupposes just such qualitative changes, which preserve the main quality of a system, the "core" of the Constitution. The reason is that each system has a concrete integrative quality, which forms the mentioned whole system and the initial condition, from which the transition to new positions takes place. Hence, in case of the absence of the given qualitative peculiarity the object ceases to be the discussed concrete system, in which case it is also impossible to speak about its stability or development.

In this regard it should be noted that according to Article 203 of the Constitution of Republic of Armenia Articles 1, 2, 3 and 203 of the Constitution shall not be subject to amendment.

The content of the mentioned non-amendable constitutional provisions is the following:

"Article 1. The Republic of Armenia is a sovereign, democratic, social state governed by the rule of law.

Article 2. In the Republic of Armenia, the power belongs to the people.

The people shall exercise their power through free elections, referenda, as well as through state and local self-government bodies and officials provided for by the Constitution.

Usurpation of power by any organization or individual shall be a crime.

Article 3. The Human Being, His or Her Dignity, Basic Rights and Freedoms

1. The human being shall be the highest value in the Republic of Armenia. The inalienable dignity of the human being shall constitute the integral basis of his or her rights and freedoms.

2. The respect for and protection of the basic rights and freedoms of the human being and the citizen shall be the duty of the public power.

3. The public power shall be restricted by the basic rights and freedoms of the human being and the citizen as a directly applicable law".

${ }^{19}$ See: Alekseev P.V., Panin A.V. Filosofiya [Philosophy]. Moscow: AST, 2005. P. 524-525. 
Therefore, the constitutional legislator considers these provisions as the basis for social relations and the fundamental elements, constituting the constitutional identity of the concrete constitutional system, hence also, prohibiting their amendment.

With regard to the above-mentioned issue it should be noted that there are not many constitutions, which include norms regarding unchangeability of particular provisions. The technique, when certain principles of the Constitution are declared as non-amendable, is more widespread ${ }^{20}$. To our mind, the latter is a more expedient approach, as it allows to preserve the initial elements, underlying the mentioned principles, simultaneously, giving an opportunity for certain changes regarding their perception, parallel to the development of the social relations. Undoubtedly, such concepts, as, for instance, "democracy", "sovereignty", "fundamental human rights and freedoms", etc, have been and are continuously developing during a time. In the $21^{\text {st }}$ century their perception does not thoroughly coincide with the one, which was, for instance, in $19^{\text {th }}$ or $20^{\text {th }}$ centuries. The perception of many terms was essentially changed even during a few decades. Hence, we believe that from this aspect the key point should be the following: the mentioned principles are subject to dynamic interpretation, within the frames of which there can be changes in the perception of certain elements of the latter, but at the same time, the elements, constituting the basis for these principles, should stay unchangeable. The Indian practice can be mentioned in this context. Notwithstanding the fact that the Constitution of India prescribes a possibility for the amendment of all the constitutional provisions, in one of its decisions the Supreme Court of India stated that the mentioned amendments cannot touch "the main structure and system" of the Constitution ${ }^{21 .}$

It should also be noted in this context that besides the necessity of preservation of the main quality, the "core" of the Constitution, there are several other conditions, which should be satisfied in order to give an opportunity for considering the changes as a development.

One of the main criteria, characterizing the term "development of the Constitution" and important in this context, is the following: in order to lead to the development the changes should be directed. This means that continuity, succession, existence of an accumulative links between the previous and the future regulations should be inherent to the qualitative changes, and the formation of the new possibilities of the system and the new constitutional solutions should be implemented

20 See: CDL-AD 001 (2010) Report on Constitutional Amendment, Adopted by the Venice Commission at its 81st Plenary Session (Venice, 11-12 December 2009). Available at: http://www.venice.coe.int/ docs/2010/CDL-AD\%282010\%29001-e.pdf (accessed: 16.05.2018)

${ }^{21}$ See: Twomey A. The Involvement of Sub-national Entities in Direct and Indirect Constitutional Amendment within Federations. Available at: (http://camlaw.rutgers.edu/statecon/workshop11greece07/ workshop11/Twomey.pdf (accessed: 17.05.2018) 
just on this basis. This is important also from the viewpoint of the issues regarding the constitutional identity and the interrelations between the latter and constitutional developments. In particular, the process of finding a balance between the typical peculiarities, providing the system a quality of uniqueness, and the ones borrowed from other systems should be guided by the necessity of ensuring an accumulative link between the previous and future features and constitutional provisions. This is also a necessary prerequisite for considering the changes as a development.

Summarizing the above-mentioned, it should be emphasized that during the constitutional developments and while finding a balance between the typical peculiarities of the system and the borrowed ones, the main quality, the "core" of the Constitution cannot be subject to fundamental changes.

In this regard we would like to touch upon the structural solutions for preserving constitutional identity in the process of constitutional developments, defined in the result of constitutional amendments of 27 November, 2015.

In the result of the mentioned amendments Article 168 of the RA Constitution prescribed that prior to the adoption of draft amendments to the Constitution, as well as draft legal acts put to referendum, the Constitutional Court determines the compliance thereof with the Constitution. In other words, determination of the so called "constitutionality" of draft constitutional amendments became an object of a preliminary mandatory constitutional supervision, which can have a rather interesting and important role from the viewpoint of preserving constitutional identity of the concrete constitutional system, hence also, the constitutional stability and stable democracy.

It should be noted that the number of constitutional courts, possessing such an authority, isn't so large. In this context the constitutional courts of Azerbaijan, Moldova, Turkey and Ukraine can be mentioned $^{22}$, each of which has its own peculiarities of the consideration of the mentioned cases.

The Constitutional Court of the Republic of Turkey, for instance, can examine and verify constitutional amendments only with regard to their form. In particular, the verification of constitutional amendments shall be restricted to consideration of whether the requisite majorities were obtained for the proposal and in the ballot, and whether the prohibition on debates under expedited procedure was observed ( the Constitution of the Republic of Turkey. Article 148$)^{23}$.

According to Article 159 of the Constitution of Ukraine a draft law on introducing amendments to the Constitution of Ukraine is considered by the Verkhovna Rada of Ukraine upon the availability of an opinion of the Constitutional Court of

${ }^{22}$ See: CDL-AD 001 (2010) Report on Constitutional Amendment... Available at: http://www.venice. coe.int/docs/2010/CDL-AD\%282010\%29001-e.pdf (accessed: 16.05.2018)

${ }^{23}$ See: The Constitution of the Republic of Turkey. Available at: https://global.tbmm.gov.tr/docs/constitution_en.pdf (accessed: 16.05.2018) 
Ukraine on the conformity of the draft law with the requirements of Articles 157 and 158 of the Constitution. Hence, it is obvious that the Constitution of Ukraine defines concrete limits for consideration of those cases, in particular, the requirements of Articles 157 and 158. Article 158 of the Constitution prescribes that the Constitution of Ukraine shall not be amended, if the amendments foresee the abolition or restriction of human and citizen's rights and freedoms, or if they are oriented toward the liquidation of the independence or violation of the territorial indivisibility of Ukraine. The Constitution of Ukraine shall not be amended in conditions of martial law or a state of emergency. Article 158, in its turn, defines that the draft law on introducing amendments to the Constitution of Ukraine, considered by the Verkhovna Rada of Ukraine and not adopted, may be submitted to the Verkhovna Rada of Ukraine no sooner than one year from the day of the adoption of the decision on this draft law. Within the term of its authority, the Verkhovna Rada of Ukraine shall not amend twice the same provisions of the Constitution.

In this context the example of the Republic of Moldova is worth mentioning, the Constitutional Court of which adopts an advisory opinion in the result of the consideration of the mentioned cases (the Constitution of the Republic of Moldova. Articles 135, 141) ${ }^{24}$.

The presented examples show that concrete criteria or limits are defined for determination of conformity in the mentioned cases. In other words, in this context we speak just about the conformity of the draft with concrete constitutional norms and requirements. Moreover, in Moldova the Constitutional Court adopts just an advisory opinion in the result of consideration of these cases.

What about the Republic of Armenia, it should be noted that Article 72 of the RA Constitutional Law "On the Constitutional Court" adopted on 17 January, 2018, prescribed the peculiarities of consideration of cases on determining the compliance of the draft amendments to the Constitution, as well as draft legal acts put to referendum, with the Constitution, defining:

"1. On the issues of the accession by the Republic of Armenia to supranational international organizations, as well as of the territorial changes of the Republic of Armenia, the National Assembly applies to the Constitutional Court prior to the adoption of the draft amendments to the Constitution, as well as draft legal acts.

2. Authorized representative of the popular initiative applies to the Constitutional Court on the draft laws submitted to referenda upon popular initiative.

3. The Constitutional Court makes a decision on the cases mentioned in the given article no latter than three months after the registration of the appeal. With a grounded procedural decision of the Constitutional Court the timeframe of the case review can be prolonged, but no longer than three months.

${ }^{24}$ See: The Constitution of the Republic of Moldova. Available at: http://www.constcourt.md/public/ files/file/Baza\%20legala/Constitutia_engl_ 13.11.17.pdf (accessed: 16.05.2018) 
4. In cases mentioned in this Article the Constitutional Court can make one of the following decisions:

1) finding the draft in conformity with the Constitution,

2) finding the draft fully or partially invalid and in non-conformity with the Constitution.

5. The Constitutional Court considers the cases mentioned in this Article in a written procedure, except in the cases when the Constitutional Court finds that the particular case gained a wide publicity or the verbal review will foster a more effective reveal of the circumstances of the case.

5. The procedural decision of the Constitutional Court on admission of case for consideration for review (according to Article 68) of law adopted within the procedure prescribed in this article is adopted by at least two-thirds vote of the total number of the judges of the Constitutional Court".

On the basis of the mentioned regulations one can conclude that the law doesn't clarify the concrete criteria of assessing the constitutionality of the draft amendments to the Constitution. Whereas, we believe that consideration of the noted cases has concrete limits, and constitutionality of the discussed draft cannot be assessed from the aspect of all the norms of the Constitution. Otherwise, the whole idea of constitutional amendments, the essence of which is changing constitutional norms, can be distorted. Another question is that those changes, as already mentioned above, cannot concern the fundamental values, constituting the "core" of the Constitution and hence, the constitutional identity of the concrete constitutional system, which circumstance, to our mind, should underlie the landmark solutions for the discussed issue.

Hence, we believe that constitutionality of draft amendments to the Constitution can be assessed from the aspect of the two main criteria: 1. from the aspect of the regulations on the procedure for constitutional amendments prescribed in the Constitution, 2. from the aspect of inviolability of fundamental constitutional values, the main quality of the Constitution, which, as mentioned above, also constitute the constitutional identity of the constitutional system and find expression in non-amendable articles of the Constitution and, more compactly, in the constitutional-legal characteristics of the state.

We believe that the mentioned circumstances should be taken into account during the consideration of the noted cases, and the constitutionality of the draft amendments to the Constitution should be assessed just from the viewpoint of the above mentioned circumstances.

\section{Conclusion}

Summarizing the presented analysis, we would like to mention that constitutional identity is the originality, individuality and uniqueness of a concrete consti- 
tutional system, everything that differentiates the mentioned constitutional system from the others. Moreover, constitutional identity includes not just the initially existing peculiar features, providing the system a quality of uniqueness, but also the peculiarities of the above-mentioned larger systems, which the constitutional system borrows and with which it starts to identify itself. In other words, constitutional identity of a concrete constitutional system is formed in the result of finding a certain balance between the peculiar features, providing the system a quality of uniqueness, and peculiarities borrowed from other systems.

\section{O-A References}

Alekseev P.V., Panin A.V. Filosofia [Philosophy]. Moscow: AST, 2005. P. 524-525 (in Russian).

Besselink L. (2010) National and Constitutional Identity before and after Lisbon. Utrecht Law Review, no 3, pp. 36-49.

Crawford J. (2015) The Criteria for Statehood in International Law. Available at: https:// www.ilsa.org/jessup/jessup 13/British\%20Yearbook\%20of\%20International\%20Law1977-Crawford-93-182.pdf (accessed: 18.04.2018)

Bushuev V., Titov V. (2014) Natsional'no-gosudarstvennaya identichnost' v sovremennom mire $i$ rol' istoricheskoy politiki v ee formirovanii (teoretiko-metodologicheskiy analiz) [National State Identity in the Modern World and the Role of Historical Politics in its Formation]. Available at: https://cyberleninka.ru/article/v/natsionalno-gosudarstvennayaidentichnost-v-sovremennom-mire-i-rol-istoricheskoy-politiki-v-ee-formirovanii-teoretiko (accessed: 18.04.2018)

Guzman A. (2011) The Consent Problem in International Law. Berkeley Program in Law and Economics. Working Paper Series. Available at: https://escholarship.org/content/ qt04x8x174/qt04x8x174.pdf (accessed: 18.04.2018)

Ispolinov A. (2017) Prioritet prava Evropeyskogo Soyuza i natsional'naya (konstitutsionnaya) identichnost' $v$ resheniyakh Suda ES i konstitutsionnykh sudov gosudarstv - chlenov EC [The Priority of EU Law and National (Constitutional) Identity in the Decisions of EU Court and Constitutional Courts of EU Member States]. Available at: https://zakon. ru/publication/prioritet_prava_evropejskogo_soyuza_i_nacionalnaya_konstitucionnaya_ identichnost_v_resheniyah_suda_e (accessed: 18.04.2018)

Kuznetsov K.A., Shchelin P.A. (2014) Natsional'naya identichnost' i ustoychivaya gosudarstvennost' [National Identity and Stable Statehood]. Sravnitel'naya politika, no 1, pp. 31-36.

Morozova L. (2010) Teoriya gosudarstva i prava [Theory of Law and State]. Moscow: Yurist, pp. 46-47 (in Russian)

National Identity, Nationalism and Constitutional Change (2009) Available at: http:// www.law.ed.ac.uk/_data/assets/pdf_file/0011/35939/chap1_intro.pdf (accessed: 18.04.2018)

Rosenfeld M. (2005) The Problem of "Identity" in Constitution-Making and Constitutional Reform. Working Paper, no 143, p. 25.

Rosenfeld M. (1998) Constitution-Making, Identity Building, and Peaceful Transition to Democracy: Theoretical Reflections Inspired by the Spanish Example. Cardozo Law Review, vol. 19, pp. 1891-1920. 
Rubtsova M., Sanina A. (2012) Gosudarstvennaya identichnost' kak factor upravlyaemosti sovremennym obshchestvom [State Identity as a Factor of Running Modern Society]. Zhurnal sotsiologii i sotsial'noy antropologii, no 3, pp. 86-97.

Sanina A., Pavlov A. (2015) Gosudarstvennaya identichnost': soderzhanie ponyatiya i postanovka problemy [State Identity: Concept and Issue]. Upravlencheskoe konsul'tirovanie, no 9, pp. 30-40.

Tribe L. (1983) Constitution We Are Amending: In Defense of a Restrained Judicial Role. Harvard Law Review, no 2, pp. 433-445.

Twomey A. (2011) The Involvement of Sub-National Entities in Direct and Indirect Constitutional Amendment within Federations. Available at: http://camlaw.rutgers.edu/statecon/workshop11greece07/workshop11/Twomey.pdf (accessed: 17.05.2018) 